\section{Efficiency of social sector expenditure in India: a case of health and education in selected Indian states}

\author{
Brijesh C. Purohit \\ Madras School of Economics, Kottur, \\ India
}

\section{Abstract}

Social sector expenditure in India captures a number of important aspects including health, nutrition, education, water supply, sanitation, housing and welfare, among others. Over a period of time, besides budgetary outlay on this sector, private sector has also played a considerable role. Thus, efficiency of expenditure in this sector by state government has to be reckoned both in terms of relative levels of various aspects across the states and in terms of comparable benchmarks for different aspects of the sector. This paper attempts an analysis of social sector efficiency focusing on two major aspects: health and education. Unlike other studies on the Indian context, this analysis focusing on major states in India uses both non-parametric and parametric approaches. Although both approaches provide benchmarks to judge relative efficiency across states, the former provides a yardstick more at an aggregative level without parametric restrictions, whereas the latter is used for major focus on health care aspects. Results of free disposal hull analysis are suggestive of a considerably more scope for improvement in efficiency of public expenditure in health relative to education. Our results of stochastic frontier analysis indicate considerable state level disparities which could be reduced through a mix of strategies involving reallocation of factors (namely, manpower and supply of consumables) within the sector, mobilizing additional resources possibly through enhanced budgetary emphasis, or encouraging more private sector participation. Based on our results, this may enhance efficiency by nearly $20 \%$ in health care sector and increase availability and equity across low performing and poorer states like Madhya Pradesh and Uttar Pradesh.

\section{Introduction}

Social sector comprises an important item in the state budgetary expenditure. It has remained around $5.8 \%$ of gross domestic product and its share in total state expenditure has varied between 36.8 (in 1990-1995) to $39.2 \%$ (2010-2011). ${ }^{1}$ Within social sector, major chunk (nearly $57 \%$ ) is being spent on education, sports, art and culture (46.1\%) and medical and public health (10.5\%). The other items which include: family welfare and water supply and sanitation, housing, urban development, welfare of scheduled castes, scheduled tribes and other backward castes, labour and labour welfare, social security and welfare, nutrition, natural calamities and the rest, comprise a low percentage which varies from 1.3\% (natural calamities) to $9.6 \%$ (social security and welfare) of total social sector. It becomes pertinent therefore to analyse whether the major expenditure sectors like health and education are performing satisfying the criteria of efficiency. Several approaches for measuring the efficiency of government expenditure have been proposed in the literature. ${ }^{2}$ In general, these approaches are broadly of four types. First, studies which have concentrated on gauging and enhancing efficiency by focusing on certain types of government spending in a specific country. Secondly, those only which use data on inputs of government spending in quantitative terms, but not on outputs. Third, those using only outputs, but not inputs. Finally, those which have looked at both inputs and outputs; these studies, however, have not made a consistent comparison of the efficiency of government spending among countries.${ }^{6}$ These studies do not explicitly analyze the relationship between government spending and social indicators. Within each of the approaches, however, one may distinguish the studies which have focussed only on developed country (or countries) or only on developing country (or countries) and further in terms of their interest in education and health sector also. Thus, the issue of gauging and enhancing government efficiency continues to interest policymakers and researchers alike..$^{2,7-9}$ This interest received a boost with the initiation of wide-ranging institutional reforms by some of the developed nations ${ }^{10-12}$ which aimed at improving the efficiency of the public sector. These reforms basically were to separate policy formulation from policy implementation, create competition between government agencies and between government agencies and private firms, and develop output-oriented budgets using a wide array of output indicators. This practice of result-oriented public expenditure management has generated a wealth of information on how to control production processes within the government and how to enhance their efficiency.

Pertaining to education sector, for instance, there are certain studies which analyse both inputs and outputs. For instance, Harbison and Hanushek ${ }^{13}$ provide an overview of 187 studies of education production functions in the United States and 96 studies of education pro-
Correspondence: Brijesh C. Purohit, Madras School of Economics, Gandhi Mandapam Road, Kottur, Chennai-600025, India.

Tel. +91.044.2230.0304 - Fax: +91.044.2235.4847.

E-mail: brijeshpurohit@gmail.com

Key words: social sector expenditure, India, health, education.

Acknowledgments: an earlier version of this paper was presented at National Conference on Social Sector in India: Issues and Challenges, March 29-30, 2013, Golden Jubilee Celebrations 2012-13, Centre of Advanced Studies, Department of Analytical and Applied Economics, Utkal University, Odisha, India. Thanks are due to participants of this conference for their valuable comments.

Received for publication: 7 August 2013.

Revision received: 2 October 2013.

Accepted for publication: 3 November 2013

This work is licensed under a Creative Commons Attribution 3.0 License (by-nc 3.0).

\section{(C) Copyright Brijesh C. Purohit 2014}

Licensee PAGEPress, Italy

Healthcare in Low-resource Settings 2014; 2:1866

doi:10.4081/hls.2014.1866

duction functions in developing countries and investigate the relation between education inputs and outputs. Another type of analysis, for instance by Tanzi and Schuknecht ${ }^{14}$ assesses the incremental impact of public spending on social and economic indicators in industrial countries and conclude that higher public spending does not significantly improve social welfare. In most studies of developing countries, it is found that teacher education, teacher experience, and the availability of facilities have a positive and significant impact on education output, and that the effect of expenditure per pupil is significant in half the studies; the pupil-teacher ratio and teacher salary have no discernible impact on education output. Likewise, Jimenez and Lockheed ${ }^{15}$ also assess the relative efficiency of public and private educations in several developing countries by taking into account both inputs and outputs. In regard to health care sector, for instance, among developed nations, using regression analysis and focusing on inputs, a study of OECD member countries covering 20 years analyzed the efficiency of health care systems. They show that public-reimbursement health systems, which combine private provision with public financing, are associated with lower public health expenditures and higher efficiency than publicly managed and financed health care systems. ${ }^{16}$ This is traced by looking at factors associated with a high relatively expensive in-patient care and the lack of a mechanism to restrain demand for special- 
ized health care. Countries without ceilings on in-patient care were also found to have higher public health expenditure. A number of studies have laid emphasis on the overall health system performance and its impact on health outcomes. ${ }^{17,18}$ More often an idealized yardstick is developed which is used to evaluate economic performance of health system. There are a number of studies in health care sector which employ either non-parametric approaches like free disposable hull (FDH) or data envelopment analysis (DEA) or parametric approaches like stochastic frontier analysis (SFA).

In the former category with a focus on developed world one may include, for instance, Aubyn $^{19}$ who used FDH covering both the health and education sectors in Portugal, Hofmarcher and colleagues ${ }^{20}$ for an Austrian province, Puig-Junoy and Gannon ${ }^{21,22}$ for Ireland, Magnussen ${ }^{23}$ for Norway, Jeffrey and Coppola ${ }^{24}$ relating to USA, Bates and colleagues $^{25}$ for the USA, Kontodimopoulos and colleagues $^{26}$ for Greek hospitals, and Spinks and Hollingsworth ${ }^{27}$ for OECD countries. Likewise, with a focus on developing nations some notable studies include a report on district hospitals in Namibia, ${ }^{28}$ Masiye $^{29}$ for Zambian hospitals, Mathiyazhgan ${ }^{30}$ for hospitals in Karnataka State in India, Mirmirani ${ }^{31}$ for transition economies of former socialist block including Albania, Armenia, Russia and others, Kittelsen and Magnussen ${ }^{32}$ for Norway, Li and Wang ${ }^{33}$ relating to Chinese public acute hospitals, Hajialiafzali and colleagues ${ }^{34}$ relating to Iran, and Suraratdechaac and Okunadeb $^{35}$ for Thialand.

In the latter type of studies using SFA, one may include with a focus on developed nations, studies for instance, by World Health Organization ${ }^{36}$ covering different nations, Murray and Frenk, ${ }^{37}$ Worthington, ${ }^{38}$ Jamison and colleagues, ${ }^{39}$ and Salomon and others ${ }^{40}$ relating to inter country comparison, Schmacker and colleagues ${ }^{41}$ relating to USA, Evans and others ${ }^{42}$ for a cross country comparison and Greene, ${ }^{43}$ Farsi and others ${ }^{44}$ relating to Switzerland, Wang and others ${ }^{45}$ for New South Wales, Kris and others $4^{6,47}$ relating to Texas, Rosko ${ }^{48}$ relating to USA, Yong and Harris $^{49}$ relating to Australia, Hollingsworth and Wildman ${ }^{50}$ for a cross country comparison, Mortimer and Peacock ${ }^{51}$ relating to Australia, and Jayasuriya and Wodon ${ }^{52}$ for a comparison among nations. Among studies focused on India one may include Sankar and Kathuria ${ }^{53}$ and Purohit. ${ }^{9,54-56}$ These latter types of studies have deployed frontier efficiency measurement techniques which involve a production possibility frontier depicting a locus of potentially technical efficient output combination that an organization or health system is capable of producing at a point of time. An output combination below this frontier is termed as technically inefficient. ${ }^{57-59}$ Despite its nascent nature of application in healthcare sector, an exhaustive review of studies applying these methods has been attempted which provides us in detail the steps and empirical problems that have been highlighted by researchers. ${ }^{38,60}$ Notably there are very few studies in the developing countries' context and except a few particularly in the Indian context, which have focused on this aspect; the literature is nearly marked by absence for recent period. Our study thus covers this gap for India for the latest period.

\section{Hypothesis and objective}

We hypothesize that States differ in their technical efficiency pertaining to health and education systems due to factors which require emphasis in facility planning in these sectors. ${ }^{9,53}$ It is also hypothesized that these factors differ from State to State according to their level of development. ${ }^{9}$ It is presumed that estimated efficiency parameters (from both types of analysis, i.e. non-parametric and parametric approaches) should help the health and education policy makers to improve State level system performance pertaining to these sectors.

\section{Materials and Methods}

\section{Non-parametric approach: free dis- posable hull}

In this paper we use two types of techniques, namely non-parametric and parametric, that allow for a direct measurement of the relative efficiency of government spending among countries or states within a nation. In the former type we apply FDH analysis which assesses the relative efficiency of production units in a market environment. This analysis consists of, first, establishing the production possibility frontier representing a combination of best-observed production results within the sample of observations (the best practices), and, second, measuring the relative inefficiency of producers inside the production possibility frontier by the distance from the frontier. The major advantages of FDH analysis are that it imposes only weak restrictions on the production technology, while allowing for a comparison of efficiency levels among producers. The only assumption made is that inputs and/or outputs can be freely disposed of, so that it is possible with the same production technology to lower outputs while maintaining the level of inputs and to increase the inputs while maintaining outputs at the same level. This assumption guarantees the existence of a continuous FDH, or production possibility frontier, for any sample of production results. Thus, FDH analysis provides an intuitive tool that can be used to identify best practices in government spending and to assess how gov- ernments are faring in comparison with these best practices. ${ }^{61-63}$ In our analysis using FDH, the term producer is meant to include governments. A producer is relatively inefficient if another producer uses less input to generate as much or more output. A producer is relatively efficient if there is no other producer that uses less input to generate as much or more output. In the Appendix and Appendix Figures $\mathrm{A}$ and $\mathrm{B}$, this is illustrated for the case of one input and one output. If a producer is engaged in the production of multiple outputs using more than one input, it becomes more difficult to establish relative efficiency. In such a situation (of multiple inputs), it is postulated that a producer is relatively inefficient if he uses as much or more of all inputs to generate as much or less of all outputs than all other producer, with at least one input being strictly higher, or one output strictly lower. Depending upon the availability of latest and comparable information, we have applied this technique for data on major and smaller Indian States for education covering different cross sections from 2003-2011 and for health covering the period 2001-2010. This analysis covers 15 major Indian States [which include Andhra Pradesh (AP), Assam, Bihar, Gujarat Harayana, Karnataka, Kerala, Madhya Pradesh (MP), Maharashtra, Orissa, Punjab, Rajasthan, Tamil Nadu (TN), Uttar Pradesh (UP), and West Bengal (WB)] and 10 smaller States [which include Arunachal Pradesh, Chhatisgarh, Goa, Himachal Pradesh (HP), Jammu and Kashmir (JK), Jharkhand, Manipur, Meghalaya, Mizoram and Nagaland].

\section{Parametric technique: stochastic frontier method}

In the application of parametric techniques, stochastic methods can be used to correct for measurement and other random errors in the estimation of the production possibility frontier. In any parametric techniques a functional form is postulated for the production possibility frontier, and then a set of parameters is selected that best fit the sample data.

\section{Model specification}

In the estimation of health system efficiency, our specification is based on a general stochastic frontier model that is presented as:

$$
\ln q_{j}=f(\ln x)+v_{j}-u_{j}
$$

where: $\ln q_{j}$ is the health output [life expectancy (LEXP) or inverse of infant mortality rates (IMR)] produced by a health system $\mathrm{j} ; \mathrm{x}$ is a vector of factor inputs represented by per capita health facilities (including per capita availability of hospital beds, per capita primary health centers (or sub centers), per capita doctors, per capita paramedical staff, per capita skilled attention for birth; $\mathrm{v}_{\mathrm{j}}$ is the stochastic 
(white noise) error term; $u_{j}$ is a one-sided error term representing the technical inefficiency of the health system $\mathrm{j}$. Both $\mathrm{v}_{\mathrm{j}}$ and $\mathrm{u}_{\mathrm{j}}$ are assumed to be independently and identically distributed with variance $s_{v}{ }^{2}$ and $s_{u}{ }^{2}$, respectively. From the estimated relationship $\ln \mathrm{q}_{\mathrm{j}}^{\wedge}=\mathrm{f}$ (ln $\mathrm{x})-\mathrm{u}_{\mathrm{j}}$, the efficient level of health outcome (with zero technical inefficiency) is defined as: $\ln \mathrm{q}^{*}=\mathrm{f}(\ln \mathrm{x})$. This implies $\ln \mathrm{TE}_{\mathrm{j}}=\ln \mathrm{q}_{\mathrm{j}}^{\wedge}-\ln$ $\mathrm{q}^{*}=-\mathrm{u}_{\mathrm{j}}$. Hence $\mathrm{TE}_{\mathrm{j}}=\mathrm{e}^{-\mathrm{u}}{ }_{\mathrm{j}}, 0<=\mathrm{e}^{-\mathrm{u}_{\mathrm{j}}}<=1$. If $\mathrm{u}_{\mathrm{j}}=0$ it implies $e^{-u}=1$. Health system is technically efficient. This implies that technical efficiency of $j^{\text {th }}$ health system is a relative measure of its output as a proportion of the corresponding frontier output. A health system is technically efficient if its output level is on the frontier which in turn means that $q / q^{*}$ equals one in value.

\section{Study design: sample and sampling technique}

This study uses secondary data published in official documents of government of India and State governments. Applying this data in any empirical study does not require any ethical approval. The study makes use of a purposive sampling and therefore focus is on 15 major Indian States. The purpose is to carry out an analysis which reveals broadly the country's scenario at state level disaggregation. Data used thus are presumed to be authentic and therefore reliable. Validity of the results is thus subject to the reliability of official publications and underlying statistical techniques deployed in the study. For parametric approach, we cover 15 major Indian States [which include Andhra Pradesh (AP), Assam, Bihar, Gujarat Harayana, Karnataka, Kerala, Madhya Pradesh (MP), Maharashtra, Orissa, Punjab, Rajasthan, Tamil Nadu (TN), Uttar Pradesh (UP), and West Bengal (WB)] and use panel data for 2005-2011. Use of panel data is preferred since it does not require strong assumptions about the error term and unlike the cross section data, the assumption of independence of technical efficiency from factor inputs is not imposed. ${ }^{64,65}$ We extend our estimation to the second stage which presumes that differences in technical efficiency pertaining to health system can be discerned at the health facility planning level from non-health related parameters. Thus, we explain the dispersion in technical efficiency by a set of variables which includes per capita income, literacy, urbanization, per capita budgetary expenditure on health and rural water supply. Thus, our model in the second stage is:

dispersion in technical efficiency $=\mathrm{f}$ (per capita income, literacy, urbanization, per capita budgetary expenditure on health and rural water supply) + error term

Thus main dependent variables used in the study are LEXP and dispersion; independent variables include per capita income and others namely, number of primary health centers
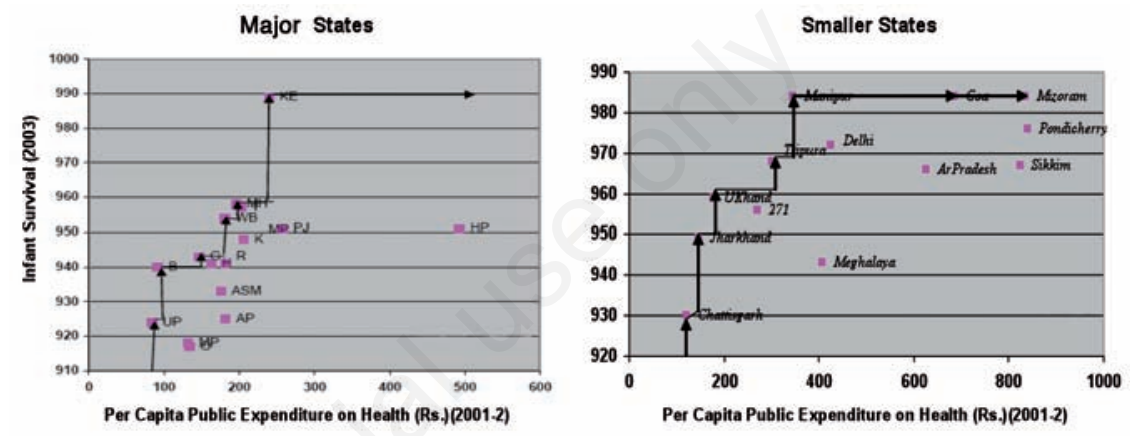

Figure 1. Independently efficient states based on infant survival in 2003 and per capita public expenditure on health in 2001-2002.

Table 1. Input efficiency score: education (2008-2011).

\begin{tabular}{|c|c|c|c|c|c|c|}
\hline States & & $\begin{array}{l}\text { Public expenditure } \\
\text { (2008-09) }\end{array}$ & $\begin{array}{l}\text { Net enrolment primary } \\
(2008-09)\end{array}$ & $\begin{array}{c}\text { IES } \\
(2008-2009)\end{array}$ & $\begin{array}{l}\text { Literacy } \\
\text { (2011) }\end{array}$ & $\begin{array}{l}\text { IES } \\
(2011)\end{array}$ \\
\hline Major & $\begin{array}{l}\text { Andhra Pradesh } \\
\text { Assam } \\
\text { Bihar } \\
\text { Gujarat } \\
\text { Harayana } \\
\text { Karnataka } \\
\text { Kerala } \\
\text { Madhya Pradesh } \\
\text { Maharashtra } \\
\text { Orissa } \\
\text { Punjab } \\
\text { Rajasthan } \\
\text { Tamil Nadu } \\
\text { Uttar Pradesh } \\
\text { West Bengal }\end{array}$ & $\begin{array}{c}1195.59 \\
1374.02 \\
725.89 \\
1015.67 \\
1615.77 \\
1429.04 \\
1661.71 \\
799.49 \\
1487.72 \\
1193.44 \\
1395.89 \\
1096.43 \\
1310.20 \\
763.40 \\
943.52\end{array}$ & $\begin{array}{l}79.12 \\
83.58 \\
53.38 \\
59.75 \\
74.14 \\
69.14 \\
84.71 \\
97.28 \\
88.93 \\
69.16 \\
74.15 \\
76.54 \\
119.56 \\
56.35 \\
87.17\end{array}$ & $\begin{array}{l}0.67 \\
0.95 \\
1.00 \\
0.79 \\
0.81 \\
0.92 \\
0.79 \\
1.00 \\
0.88 \\
0.67 \\
0.94 \\
0.73 \\
1.00 \\
1.00 \\
0.85\end{array}$ & $\begin{array}{l}67.66 \\
73.18 \\
63.82 \\
79.31 \\
76.64 \\
75.60 \\
93.91 \\
70.63 \\
82.91 \\
73.45 \\
76.68 \\
67.06 \\
80.33 \\
69.72 \\
77.08\end{array}$ & $\begin{array}{l}0.85 \\
0.74 \\
1.00 \\
1.00 \\
0.92 \\
0.71 \\
1.00 \\
1.00 \\
1.00 \\
0.85 \\
0.73 \\
0.93 \\
0.78 \\
1.00 \\
1.00\end{array}$ \\
\hline Minor & $\begin{array}{l}\text { Arunachal Pradesh } \\
\text { Chhatisgarh } \\
\text { Goa } \\
\text { Himachal Pradesh } \\
\text { Jammu and Kashmir } \\
\text { Jharkhand } \\
\text { Manipur } \\
\text { Meghalaya } \\
\text { Mizoram } \\
\text { Nagland }\end{array}$ & $\begin{array}{l}3684.77 \\
1211.87 \\
4648.96 \\
3299.52 \\
1497.35 \\
1162.75 \\
2054.26 \\
2110.56 \\
3780.70 \\
2339.54 \\
\end{array}$ & $\begin{array}{c}115.15 \\
88.30 \\
62.04 \\
115.11 \\
100.69 \\
73.18 \\
83.20 \\
83.46 \\
104.75 \\
88.34\end{array}$ & $\begin{array}{l}1.03 \\
1.00 \\
0.81 \\
1.00 \\
1.00 \\
1.00 \\
0.73 \\
0.71 \\
1.00 \\
0.64\end{array}$ & $\begin{array}{l}66.95 \\
71.04 \\
87.40 \\
83.78 \\
68.74 \\
67.63 \\
79.85 \\
75.48 \\
91.58 \\
80.11\end{array}$ & $\begin{array}{l}0.90 \\
1.00 \\
0.81 \\
1.00 \\
\\
1.00 \\
1.00 \\
0.97 \\
1.00 \\
1.00\end{array}$ \\
\hline
\end{tabular}

IES, input efficiency score. 
(PHCs), sub-centers (SCs), community health centers (CHCs), hospitals and dispensaries, health manpower-medical and paramedical, and socio-economic parameters like income, education, and basic amenities, etc.

\section{Database}

This study is based on secondary data. Information is collected for the years 2005-11 from various sources including RBI Bulletin, ${ }^{1}$ Health Information of India ${ }^{66-72}$ and other published sources. At the all-India level, main variables used in the study are LEXP, IMR, per capita income and other parameters related to health infrastructure including number of PHCs, SCs, CHCs, hospitals and dispensaries, health manpower-medical and paramedical, and other variables relevant for depicting healthcare facilities, their utilization, health outcomes, socio-economic parameters like income, education, and basic amenities, etc. Statistical analysis tools used by our study include frontier regression technique applying STATA software.

\section{Results}

The results of our FDH analysis for educa-
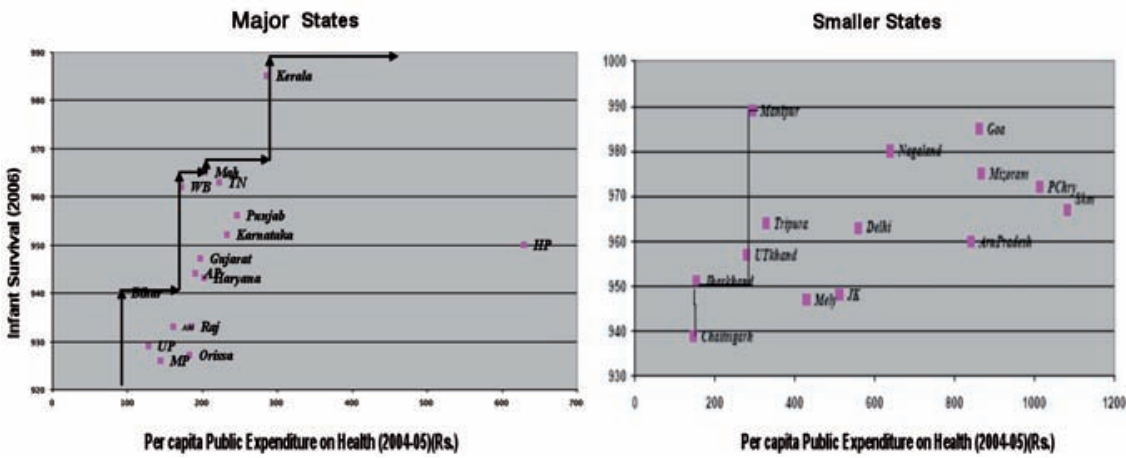

Figure 2. Independently efficient states based on infant survival in 2006 and per capita public expenditure on health in 2004-2005.

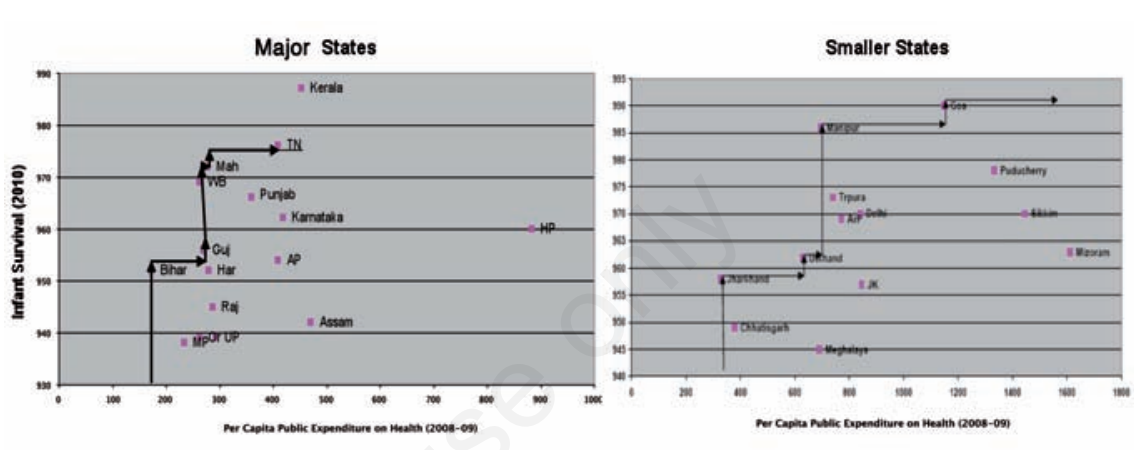

Figure 3. Independently efficient states based on infant survival in 2010 and per capita public expenditure on health in 2008-2009.

Table 2. Input efficiency score: health (2001-2005).

\begin{tabular}{|c|c|c|c|c|c|c|c|}
\hline States & & $\begin{array}{l}\text { Public expenditure } \\
\text { (2001-2002) }\end{array}$ & $\begin{array}{c}\text { Infant survival } \\
\text { (2003) }\end{array}$ & IES & $\begin{array}{l}\text { Public expenditure } \\
\text { (2004-05) }\end{array}$ & $\begin{array}{l}\text { Infant survival } \\
\text { (2006) }\end{array}$ & IES \\
\hline Major & $\begin{array}{l}\text { Andhra Pradesh } \\
\text { Assam } \\
\text { Bihar } \\
\text { Gujarat } \\
\text { Haryana } \\
\text { Karnataka } \\
\text { Kerala } \\
\text { Madhya Pradesh } \\
\text { Maharashtra } \\
\text { Orissa } \\
\text { Punjab } \\
\text { Rajasthan } \\
\text { Tamil Nadu } \\
\text { Uttar Pradesh } \\
\text { West Bengal }\end{array}$ & $\begin{array}{c}182 \\
176 \\
92 \\
147 \\
163 \\
206 \\
240 \\
132 \\
196 \\
134 \\
258 \\
182 \\
202 \\
84 \\
181\end{array}$ & $\begin{array}{l}941 \\
933 \\
940 \\
943 \\
941 \\
948 \\
989 \\
918 \\
958 \\
917 \\
951 \\
925 \\
957 \\
924 \\
954\end{array}$ & $\begin{array}{c}0.81 \\
0.83 \\
1 \\
1 \\
0.90 \\
0.95 \\
1 \\
0.69 \\
1 \\
1.09 \\
0.93 \\
0.81 \\
1.18 \\
1 \\
1\end{array}$ & $\begin{array}{c}191 \\
162 \\
93 \\
198 \\
203 \\
233 \\
287 \\
145 \\
204 \\
183 \\
247 \\
186 \\
223 \\
128 \\
173\end{array}$ & $\begin{array}{l}944 \\
933 \\
940 \\
947 \\
943 \\
952 \\
985 \\
926 \\
965 \\
927 \\
956 \\
933 \\
963 \\
929 \\
962\end{array}$ & $\begin{array}{l}0.91 \\
1.07 \\
1.00 \\
0.87 \\
1.00 \\
0.88 \\
1.00 \\
0.64 \\
1.00 \\
0.95 \\
0.83 \\
0.93 \\
0.91 \\
0.73 \\
1.00\end{array}$ \\
\hline Smaller & $\begin{array}{l}\text { Arunachal Pradesh } \\
\text { Chattisgarh } \\
\text { Delhi } \\
\text { Goa } \\
\text { Himachal Pradesh } \\
\text { Jammu and Kashmir } \\
\text { Jharkhand } \\
\text { Manipur } \\
\text { Meghalaya } \\
\text { Mizoram } \\
\text { Pondicherry } \\
\text { Sikkim } \\
\text { Tripura } \\
\text { Uttarakhand } \\
\text { Nagaland }\end{array}$ & $\begin{array}{l}627 \\
121 \\
426 \\
685 \\
493 \\
271 \\
146 \\
345 \\
407 \\
836 \\
841 \\
825 \\
301 \\
178 \\
\text { na }\end{array}$ & $\begin{array}{l}966 \\
930 \\
972 \\
984 \\
951 \\
956 \\
949 \\
984 \\
943 \\
984 \\
976 \\
967 \\
968 \\
959 \\
\text { na }\end{array}$ & $\begin{array}{c}0.55 \\
1 \\
0.81 \\
1 \\
0.49 \\
0.66 \\
1 \\
1 \\
0.85 \\
1 \\
0.99 \\
1.01 \\
1 \\
1 \\
\text { na }\end{array}$ & $\begin{array}{c}841 \\
146 \\
560 \\
861 \\
630 \\
512 \\
155 \\
294 \\
430 \\
867 \\
1014 \\
1082 \\
328 \\
280 \\
639\end{array}$ & $\begin{array}{l}960 \\
939 \\
963 \\
985 \\
950 \\
948 \\
951 \\
989 \\
947 \\
975 \\
972 \\
967 \\
964 \\
957 \\
980\end{array}$ & $\begin{array}{l}0.35 \\
1.00 \\
0.53 \\
0.34 \\
0.46 \\
0.57 \\
1.00 \\
1.00 \\
0.68 \\
0.34 \\
0.29 \\
0.27 \\
0.90 \\
1.00 \\
0.46\end{array}$ \\
\hline
\end{tabular}

IES, input efficiency score; na, not available. 
tion and health sector using data for Indian states, both major and smaller ones, are presented below in Figures 1-5 and Tables 1-3.

\section{Free disposable hull analysis}

It can be observed that for per capita public expenditure on health (in 2001-02), independently efficient states that emerged from FDH for major states are UP, Bihar, Gujarat West Bengal, Maharashtra and Kerala (Figure 1). Among the smaller states the independently efficient states are Chhatisgarh, Jharkhand, Uttarakhand, Tripura and Manipur (Figure 1). Likewise, in Figure 2 (for 2004-2005 per capita public expenditure), the situation is somewhat changed for UP whereas other independently efficient states remain the same. Among smaller states a changed situation with lower efficiency is depicted for Tripura only (Figure 2 ). Free disposable hull for public expenditure in 2008-09 for health sector (Figure 3) depict additional states namely WB and Tamil Nadu among independently efficient states (Figure 3 ) and inclusion and exclusion of Goa and Chhatisgarh respectively in the category of such (independently efficient) states (Figure $3)$. In education sector, using literacy (2011) and public expenditure (2008-09), the states like Bihar, UP, WB, Gujarat, Tamil Nadu. Maharashtra and Kerala (among major states) and Jharkhand, Chhatisgarh, Manipur and
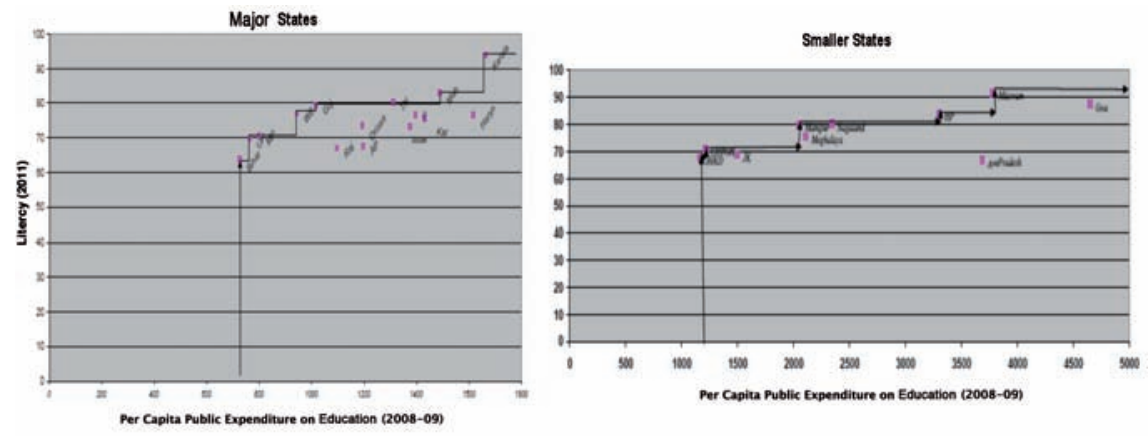

Figure 4. Independently efficient states based on literacy in 2011 and per capita public expenditure on education in 2008-2009.
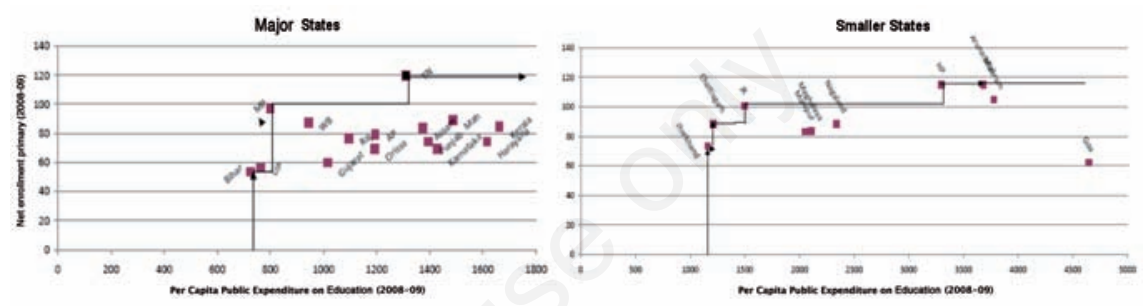

Figure 5. Independently efficient states based on net enrolment primary in 2008-2009 and per capita public expenditure education in 2008-2009.

Table 3. Input efficiency score: health (2010).

\begin{tabular}{|c|c|c|c|c|}
\hline States & & Public expenditure (2008-2009) & Infant survival rate (2010) & IES \\
\hline \multirow[t]{15}{*}{ Major } & Andhra Pradesh & 410.00 & 954.00 & 1.00 \\
\hline & Assam & 471.00 & 942.00 & 0.96 \\
\hline & Bihar & 173.00 & 952.00 & 1.00 \\
\hline & Gujarat & 270.00 & 956.00 & 1.00 \\
\hline & Harayana & 280.00 & 952.00 & 0.99 \\
\hline & Karnataka & 419.00 & 962.00 & 0.98 \\
\hline & Kerala & 454.00 & 987.00 & 1.00 \\
\hline & Madhya Pradesh & 235.00 & 938.00 & 0.74 \\
\hline & Maharashtra & 278.00 & 972.00 & 1.00 \\
\hline & Orissa & 263.00 & 939.00 & 1.06 \\
\hline & Punjab & 360.00 & 966.00 & 0.77 \\
\hline & Rajasthan & 287.00 & 945.00 & 0.97 \\
\hline & Tamil Nadu & 410.00 & 976.00 & 1.00 \\
\hline & Uttar Pradesh & 293.00 & 939.00 & 0.95 \\
\hline & West Bengal & 262.00 & 969.00 & 1.00 \\
\hline \multirow[t]{14}{*}{ Smaller } & Arunachal Pradesh & 771.00 & 969.00 & 0.90 \\
\hline & Chhattisgarh & 378.00 & 949.00 & 0.87 \\
\hline & Delhi & 840.00 & 970.00 & 0.83 \\
\hline & Goa & 1149.00 & 990.00 & 1.00 \\
\hline & Himachal Pradesh & 884.00 & 960.00 & 0.96 \\
\hline & Jammu and Kashmir & 845.00 & 957.00 & 0.82 \\
\hline & Jharkhand & 328.00 & 958.00 & 1.00 \\
\hline & Manipur & 695.00 & 986.00 & 1.00 \\
\hline & Meghalaya & 690.00 & 945.00 & 0.91 \\
\hline & Mizoram & 1611.00 & 963.00 & 0.71 \\
\hline & Puducherry & 1333.00 & 978.00 & 0.86 \\
\hline & Sikkim & 1446.00 & 970.00 & 0.79 \\
\hline & Tripura & 740.00 & 973.00 & 0.94 \\
\hline & Uttarakhand & 630.00 & 962.00 & 1.00 \\
\hline
\end{tabular}

IES, input efficiency score. 
Himachal Pradesh (among smaller states) emerge as independently efficient states (Figure 4). By and large a similar observation could be made using net enrolment primary in 2008-09 (Figure 5). Using this FDH analysis, input efficiency scores (IES) are presented in Tables 1-3. It could be observed that there is a range of $7-25 \%$ for major states and a scope of nearly $10 \%$ for smaller states to improve their input efficiency relative to nearest independently efficient states in 2011 for education sector (Table 1). In case of health sector, this range is much higher for some years like 20042005 (Table 2) and it has been 1-13\% for major states and 6-30\% for smaller states for the year 2010 (Table 3).

\section{Stochastic frontier method}

In the application of parametric techniques, stochastic methods can be used to correct for measurement and other random errors in the estimation of the production possibility frontier. In any parametric techniques a functional form is postulated for the production possibility frontier, and then a set of parameters is selected that best fit the sample data. Results of our panel data estimation using frontier model for India (Males and females) are presented in Table 4. It is observed that all the independent variables to explain LEXP have emerged with appropriate positive signs. Three of these variables, i.e. rural specialists (total specialists), auxiliary nurse midwife (ANM)/female health worker, and total number of blood banks are statistically significant.

\section{Discussion}

Results of our FDH analysis are suggestive of a considerably more scope for improvement in efficiency of public expenditure in health relative to education. Further parametric approach of SFA indicates factors that could be isolated to suggest ways to improve efficiency in the public expenditure in the sector. As mentioned ear-

Table 4. Stochastic frontier panel data model for India: life expectancy male and female (2005-2011).

\begin{tabular}{|c|c|c|c|c|}
\hline \multirow[t]{2}{*}{ Variables } & \multicolumn{2}{|c|}{ Coefficient } & \multicolumn{2}{|c|}{$\mathbf{z}$} \\
\hline & M & F & M & $\mathbf{F}$ \\
\hline Total specialists & 0.004 & 0.004 & $1.83^{* *}$ & $1.8^{* *}$ \\
\hline Auxiliary nurse midwife & 0.014 & 0.017 & $2.12^{*}$ & $2.57 * * *$ \\
\hline Total no. blood bank & 0.043 & 0.048 & $3.25^{* * *}$ & $3.21^{* * *}$ \\
\hline Constant & 3.929 & 3.942 & $52.360^{* * *}$ & $46.21^{* * *}$ \\
\hline $\mathrm{Mu}$ & 0.081 & 0.112 & $3.520^{* * *}$ & $4.59^{* * *}$ \\
\hline Lnsigma2 & -5.802 & -5.546 & $-10.910^{* * *}$ & $-11.810^{* * *}$ \\
\hline Ilgtgamma & 2.879 & 3.144 & $4.890^{* * *}$ & $6.09 * * *$ \\
\hline Sigma2 & 0.003 & 0.004 & - & - \\
\hline Gamma & 0.947 & 0.959 & - & - \\
\hline Sigma_U2 & 0.003 & 0.004 & - & - \\
\hline Sigma_V2 & 0.000 & 0.000 & - & - \\
\hline
\end{tabular}

Table 5. Actual and estimated life expectancy for males and females in selected Indian States (2010).

\begin{tabular}{|c|c|c|c|c|c|c|c|c|}
\hline \multirow[t]{2}{*}{ State } & \multicolumn{2}{|c|}{$\begin{array}{l}\text { Actual } \\
\text { LEXP }\end{array}$} & \multicolumn{2}{|c|}{$\begin{array}{l}\text { Potential } \\
\text { LEXP }\end{array}$} & \multicolumn{2}{|c|}{$\begin{array}{l}\text { Actual as } \% \\
\text { of potential } \\
\text { LEXP }\end{array}$} & \multicolumn{2}{|c|}{$\begin{array}{l}\text { Ranks of States according } \\
\text { to realization of potential } \\
\text { LEXP }\end{array}$} \\
\hline & M & F & M & F & M & F & M & $\mathrm{F}$ \\
\hline Andhra Pradesh & 65.40 & 69.40 & 76.17 & 82.01 & 85.86 & 84.62 & 14 & 12 \\
\hline Assam & 61.60 & 62.80 & 70.12 & 74.67 & 87.85 & 84.10 & 11 & 13 \\
\hline Bihar & 67.10 & 66.70 & 70.24 & 74.84 & 95.52 & 89.13 & 4 & 9 \\
\hline Gujarat & 67.20 & 71.00 & 72.33 & 77.33 & 92.90 & 91.82 & 6 & 5 \\
\hline Haryana & 67.90 & 69.80 & 69.61 & 74.03 & 97.54 & 94.29 & 2 & 3 \\
\hline Karnataka & 66.50 & 71.10 & 73.57 & 78.74 & 90.39 & 90.29 & 8 & 7 \\
\hline Kerala & 72.00 & 76.80 & 73.10 & 78.13 & 98.49 & 98.29 & 1 & 1 \\
\hline Madhya Pradesh & 62.50 & 63.30 & 72.91 & 78.04 & 85.72 & 81.11 & 15 & 14 \\
\hline Maharashtra & 67.90 & 81.78 & 75.99 & 87.19 & 89.35 & 93.79 & 10 & 4 \\
\hline Odisha & 62.30 & 64.80 & 70.99 & 75.65 & 87.76 & 85.65 & 12 & 11 \\
\hline Punjab & 68.70 & 71.60 & 70.83 & 75.45 & 96.99 & 94.90 & 3 & 2 \\
\hline Rajashthan & 66.10 & 69.20 & 72.06 & 77.00 & 91.73 & 89.87 & 7 & 8 \\
\hline Tamilnadu & 67.60 & 70.60 & 75.17 & 80.70 & 89.92 & 87.49 & 9 & 10 \\
\hline Uttar Pradesh & 64.00 & 64.40 & 74.48 & 79.95 & 85.93 & 80.55 & 13 & 15 \\
\hline West Bengal & 68.20 & 70.90 & 72.34 & 77.37 & 94.28 & 91.64 & 5 & 6 \\
\hline
\end{tabular}

LEXP, life expectancy. 
lier, we hypothesize that States differ in their technical efficiency pertaining to health system due to factors which require emphasis in health facility planning. It is also hypothesized that these factors differ from State to State according to their level of development. It is presumed that estimated efficiency parameters should help the health policy makers to improve State level health system performance. As presented in the results above our findings indicate positive impact of governmental intervention in expansion of PHC facilities and the desirable impact of having rural specialists like surgeons, obstetrician and gynaecologists, physicians and paediatricians for enhancing life expectancy. The fact that the ANM has emerged with positive signs is indicative of the desirable role of the various inputs provided through paramedical manpower. Statistical significance of these inputs at the conventional level of significance and the variable of blood bank suggest that the system has indeed worked towards providing some of the desirable inputs. However, whether these have been utilised as efficiently as to be considered as optimum is revealed through our comparison of actual and estimated LEXP for males for the year 2010 in Table 5. These depict Kerala as the most efficient State with its actual LEXP being the highest in the estimated LEXP. This is followed by Punjab and Haryana. Further, the lowest efficiency for males is depicted by Madhya Pradesh followed by Andhra Pradesh and Uttar Pradesh. In case of Female life expectancy these rankings for the latter type (i.e., moving from lowest ranking state) are depicted by Uttar Pradesh followed by Madhya Pradesh and Assam (Table 5). Reasons for these inter-State disparities can be deciphered from major inputs for health sector in the States. Notably, the distributions of: per capita hospitals, PHCs, SCs, CHCs and beds in the States are highly inequitable. In fact, there is a considerable difference between maximum and minimum values for each of the parameters. ${ }^{72}$ Pertinently population served per government hospital bed is the highest (5606) in Bihar, followed by Assam (3912) and Uttar Pradesh (3499). Similar order holds true with regard to Population Served per govt hospital with highest figure for Bihar (451325) followed by Uttar Pradesh (229118) and Assam (194863). The magnitude of the highest and the lowest Population Served Per Government hospital bed and hospitals in the States is ranked slightly different from order that of life expectancy and its achievements (i.e., actual $v s$ potential life expectancy) in our results. However, observations pertaining to other facilities like PHCs, SCs and CHCs depict higher numbers per thousand populations in Uttar Pradesh, which is in contrast to its lowest ranking of life expectancy outcomes thus depicting inadequate utilisation of these facilities. It is pertinent to note that
Kerala does not have the highest number for any of the categories of these. ${ }^{72}$ In fact, in terms of manpower again Uttar Pradesh seems to have highest per thousand specialists at $\mathrm{CHC}$ (1.89), health assistants (4.52) and ANMs (22.46) and it has the second highest number for doctors at PHCs (2.86) and lady health visitor (2.04) in the country. This pattern also reinforces the lower utilisation of manpower in the state. It points to the inadequate or ineffective utilization of staff inputs in poorly performing states. However, in most of the States, neither the inadequate availability of healthcare sector inputs nor merely inefficient utilization of these inputs explains the differentials in achievements in life expectancy. Besides the factors within the health system, as noted by us earlier, there are influences external to the system that may lead to differentials in efficiency at the State level. Some of these factors could be per capita income, per capita budgetary health expenditure, literacy, access to safe drinking water and urbanization. In general, the differential impact on life expectancy of health system inputs may be due to significant influence of some of these variables. It could be observed from the official publications that the majority of poorly performing States like Uttar Pradesh, Madhya Pradesh and Bihar are among the low income category States. ${ }^{73}$ Even the budgetary expenditure (as percent to total state budget) is lower in some of these States like Madhya Pradesh but this also holds for some of the relatively better off States like Punjab, Haryana and Maharashtara. ${ }^{73}$ Although Kerala does not have the highest figures in terms of either per capita income or budgetary expenditure on health, yet it has an outstanding position in terms of overall literacy which is 90.91 percent as per the 2011 census. ${ }^{73}$ In contrast, many of the poor and poorly performing States, in terms of life expectancy, have much lower levels of literacy. A similar situation prevails in terms of level of urbanisation in poorer states relative to their counterparts in better off states. ${ }^{73}$ Thus, in order to explore such external factors, we used dispersion in efficiency as a dependent variable in the second stage of our regression exercise using panel data for the state level. These are presented in the Appendix and Appendix Table A. The positive sign of per capita income indicates the impact of inequality in income across states influencing the inequality in health outcomes towards greater disparities. The negative sign of gross enrolment indicates that an increased level of awareness about health related facilities and issues have helped to reduce regional disparity in efficiency of health system across states. However, this has not been able to compensate for other deficiencies of low investments and poor utilization of existing heath care facilities.

\section{Conclusions}

Results of our FDH analysis are suggestive of a considerably better scope for improvement in efficiency of public expenditure in health relative to education. Further parametric approach of SFA applied for health care sector indicates factors that could be isolated to suggest ways to improve efficiency in the public expenditure in the sector. The results of the frontier model, using panel data for 15 major Indian States in the years 2005-2011, indicate that the efficiency of public health delivery system remains low. Considerable disparities across States in terms of per capita availability and utilization of hospitals, beds and manpower inputs has had an adverse impact on improving the life expectancy in the poorer States. Overcoming these factoral disparities within the health system may lead to an improvement in the State level efficiency of the public health system. This may also help to improve life expectancy speedily and more equitably in the poorly performing States of Madhya Pradesh and Uttar Pradesh possibly as much as by $20 \%$. However, this has to be supported with other adequate infrastructure facilities like more budgetary expenditure to improve availability of medicines and materials at rural facilities and better management of health personnel in the rural areas to ensure their adequate utilisation. Learning from the remarkable achievements of Kerala, an emphasis on literacy by reducing dropout rates along with better utilization of health infrastructure and manpower resources could go a long way in improving life expectancy. This may require a considerable re-orientation of current healthcare set-up, particularly in the rural areas in the poorly performing States. These could reallocate surplus manpower from within and also make the rural infrastructure more useful to the needy through adequate inputs of building, equipment and medicines. In fact, there is a considerable differential in budgetary expenditure per capita between better off and poorer States. This in turn reduces the availability of basic medicines and materials in the public health system and reduces its reliability for the poor making them more dependent on the costlier private sector. Part of this problem could be tackled through funds from National Rural Health Mission and also by improving rural sanitation in poorer States. The results also suggest lack of appropriate links and coordination between economic and social sector policies leading to sub-optimal health outcomes for the poorer States in the country. Our results of SFA for 2005-2011 corroborate the analysis for earlier periods from other studies like Sankar and Vinish ${ }^{53}$ and Purohit. $^{9}$ 


\section{References}

1. Reserve Bank of India. State finances 2011. Mumbai: Bank of India Publ.; 2012.

2. Gupta S, Honjo K, Verhoeven M. The efficiency of government expenditure: experiences from Africa. Washington, DC: International Monetary Fund; 1997.

3. Isenman PJ. Basic needs: the case of Sri Lanka. World Dev 1980;8:237-58.

4. Sen AK. Public action and the quality of life in developing countries. Oxford B Econ Stat 1981;43:287-319.

5. Aturupane H, Glewwe P, Isenman PI. Poverty, human development and growth: an emerging consensus? Washington: The World Bank, Human Resources and Operations Policy Department Publ.; 1994.

6. Kakwani N. Performance in living standards: an international comparison. J Dev Econ 1993;41:307-36.

7. Ke-Young C, Hemming R, eds. Public expenditure handbook: a guide to public expenditure policy issues in developing countries. Washington, DC: International Monetary Fund Publ.; 1991.

8. Ke-Young C, Gupta S, Clements B, et al. Unproductive public expenditures: a pragmatic approach to policy analysis. Washington: International Monetary Fund Publ.; 1995.

9. Purohit BC. Health care system in India. New Delhi: Gayatri Publ.; 2010.

10. Scott GC. Government reform in New Zealand. Washington: International Monetary Fund Publ.; 1996.

11. Oxley H, Maher M, Martins P, Nicoletti G. The public sector: issues for the 1990s. Paris: Organization for Economic Cooperation and Development Publ.; 1990.

12. OECD. Performance management in government: performance measurement and results-oriented management. Paris: Organization for Economic Cooperation and Development Publ.; 1994.

13. Harbison RW, Hanushek EA. Educational performance of the poor: lessons from rural Northeast Brazil. Oxford: Oxford University Press; 1992.

14. Tanzi V, Schuknecht L. Reconsidering the fiscal role of government: the international perspective. Am Econ Rev 1997;87:164-8.

15. Jimenez E, Lockheed ME. Public and private secondary education in developing countries: a comparative study. Washington, DC: World Bank; 1995.

16. Gerdtham VG, Jonsson B, MacFarlan M, Oxley H. New directions in health care policy. Paris: Organization for Economic Cooperation and Development Publ.; 1995.

17. Evans DB, Tandon A, Murray CJL, Lauer JA. The comparative efficiency of national health systems in producing health: an analysis of 191 countries. Geneva: World Health Organization Publ.; 2001.

18. Wang J, Jamison DT, Bos E, et al. Measuring country performance on health: selected indicators for 115 countries. Washington, DC: IBRD/World Bank; 1999.

19. St. Aubyn M. Evaluating efficiency in the Portuguese health and education sectors. Economia 2002;26:1-53.

20. Hofmarcher MM, Paterson I, Riedel M. Measuring hospital efficiency in Austria: a DEA approach. Health Care Manage Sci 2002;5:7-14.

21. Puig-Junoy J. Technical efficiency in the clinical management of critically ill patients. Health Econ 1998;7:263-77.

22. Gannon B. Technical efficiency of hospitals In Ireland. Dublin: Economic and Social Research Institute Publ.; 2004.

23. Magnussen J. Efficiency measurement and the operationalization of hospital production. Health Serv Res 1996;31:21-37.

24. Jeffrey P, Coppola MN. Efficiency of federal hospitals in the United States. J Med Syst 2004;28:411-22.

25. Bates LJ, Kankana M, Santerre RE. Market structure and technical efficiency in the hospital services industry: a DEA approach. Med Care Res Rev 2006;63:499524.

26. Kontodimopoulos N, Nanos P, Niakas D. Balancing efficiency of health services and equity of access in remote areas. Health Policy 2003;76:49-57.

27. Spinks J, Hollingsworth B. Health production and the socioeconomic determinants of health in OECD countries: the use of efficiency models. Clayton: Centre for Health Economics, Monash University; 2005.

28. Government of the Republic of Namibia. The technical efficiency of district hospitals in Namibia. Windhoek: Ministry of Health And Social Service; 2004.

29. Masiye F. Investigating health system performance: an application of data envelopment analysis to Zambian hospitals. BMC Health Serv Res 2007;7:58.

30. Mathiyazhgan MK. Cost efficiency of public and private hospitals: evidence from Karnataka State in India. Hon Sui Sen: Institute of South Asian Studies; 2006.

31. Mirmirani S. Health care efficiency in transition economies: an application of data envelopment analysis. Int Business Econ Res J 2008;7:47-56.

32. Kittelsen Sverre AC, Magnussen J. Testing DEA models of efficiency in Norwegian psychiatric outpatient clinics. Oslo: Health Economics Research programme at the University of Oslo 1998-2003; 1999. Available from: http://www.frisch.uio.no/english/publica- tions/?pubid=93

33. Li L, Wang J. Relative efficiency of the Chinese public acute hospitals: an empirical data envelopment analysis application. Hong Kong: Department of Management, The Hong Kong Polytechnic University; 2008.

34. Hajialiafzali H, Moss JR, Mahmood MA. Efficiency measurement for hospitals owned by the Iranian social security organisation. J Med Syst 2007;31:166-72.

35. Suraratdechaac C, Albert A. Okunadeb AA. Measuring operational efficiency in a health care system: a case study from Thailand. Health Policy 2006;77:2-23.

36. WHO. The world health report, 2000. Health systems: improving performance. Geneva: World Health Organisation; 2000.

37. Murray CJL, Frenk J. A WHO framework for health system performance assessment, Global programme on evidence and information for policy. Washington, DC: World Bank; 1999.

38. Worthington AC. Frontier efficiency measurement in health care: a review of empirical techniques and selected applications. Med Care Res Rev 2004;61:135-70.

39. Jamison DT, Sandbu M, Wang J. Cross country variation in mortality decline, 1962-87: the role of country specific technical progress. Geneva: Commission on Macroeconomics and Health, World Health Organization; 2001.

40. Salomon JA, Mathers CD, Murray CJL, Ferguson B. Method for life expectancy and healthy life expectancy uncertainty analysis. Geneva: Global Programme on Evidence for Health Policy, World Health Organization; 2001.

41. Schmacker ER, McKay NL. Factors affecting productive efficiency in primary care clinics. Health Serv Res 2008;21:60-70.

42. Evans DB, Tandon A, Murray CJL, Lauer JA. The comparative efficiency of national health systems in producing health: an analysis of 191 countries. Geneva: World Health Organization; 2000.

43. Greene W. Fixed and random effects in stochastic frontier models. New York, NY: Department of Economics, Stern School of Business, New York University; 2002.

44. Mehdi F, Filippini M, Lunati D. Economies of scale and efficiency measurement in Switzerland's nursing homes. Paris: OECD; 2007.

45. Jian W, Zhao Z, Mahmood A. Relative efficiency, scale effect, and scope effect of public hospitals: evidence from Australia. Newcastle: University of Newcastle; 2006.

46. Knox KJ, Blankmeyer EC, Stutzman JR. Efficiency of nursing home chains and the implications of nonprofit status: a comment. J Real Estate Port Manage 2001;7:177-82. 
47. Knox KJ, Blankmeyer EC, Stutzman JR. Technical efficiency in Texas nursing facilities: a stochastic production frontier approach. J Econ Fin 2007;31:75-86.

48. Rosko MD. Cost efficiency of US hospitals: a stochastic frontier approach. Health Econ 2001;10:539-51.

49. Yong K, Harris A. Efficiency of hospitals in Victoria under casemix funding: a stochastic frontier approach. Clayton: Centre for Health Program Evaluation, Monash University; 1999.

50. Hollingsworth B, Wildman J. The efficiency of health production: re-estimating the WHO panel data using parametric and nonparametric approaches to provide additional information. Clayton: Centre for Health Programme Evaluation, Monash University; 2002.

51. Mortimer D, Peacock S. Hospital efficiency measurement: simple ratios vs. frontier methods. Clayton: Centre for Health Program Evaluation, Monash University; 2000.

52. Jayasuriya R, Wodon Q. Measuring and explaining country efficiency in improving health and education indicators. Washington, DC: World Bank; 2002.

53. Sankar D, Vinish K. Health system performance in rural India efficiency estimates across states. Econ Polit Weekly 2004;27:1427-33.

54. Purohit BC. Efficiency variation at substate level: the health care system in Karnataka. Econ Polit Weekly 2010;47:70

\section{6.}

55. Purohit BC. Efficiency of health care system at sub-state level in Madhya Pradesh (India). Soc Work Public Health 2010;25:42-58.

56. Purohit BC. Efficiency of health care sector at sub-state level in India: a case of Punjab. Online J Health All Sci 2010;8:2.

57. Fried HO, Lovell CA, Schmidt SS. the measurement of productive efficiency: techniques and applications. New York, NY: Oxford University Press; 1993.

58. Charnes A, Cooper WW, Lewin AY, Seiford LM. Data envelopment analysis: theory, methodology and applications. Boston: Kluwer; 1995.

59. Coelli T, Rao DSP, Battese G. An introduction to efficiency and productivity analysis. Boston: Kluwer; 1998.

60. Hollingsworth B, Dawson PJ, Maniadakis N. Efficiency measurement of health care: a review of non-parametric methods and applications. Health Care Manage Sci 1999;2:161-72.

61. Deprins D, Simar L, Tulkens H. Measuring labor-efficiency in post offices. Amsterdam: North-Holland; 1984.

62. Tulkens H, Vanden Eeckaut P. Non-parametric efficiency, progressmand regress measures for panel data: methodological aspects. Eur J Oper Res 1995;80:474-9.

63. Fakin B, de Crombrugghe A. Fiscal adjustment in transition economies: social transfers and the efficiency of public spending. Comparative analysis with
OECD countries. Washington, DC: World Bank; 1999. Available from: elibrary.worldbank.org/doi/pdf/10.1596/1813-9450-1803

64. Pitt M, Lee M. The measurement and sources of technical inefficiency in the Indonesian weaving industry. J Dev Econ 1981;9:43-64.

65. Schmidt P, Sickles RC. Production frontiers and panel data. J Bus Econ Stat 1984;2:309-16.

66. Government of India. Health Information of India, 2005. New Delhi: CBHI, DGHS, MOHFW; 2006.

67. Government of India. Health Information of India, 2006. New Delhi: CBHI, DGHS, MOHFW; 2007.

68. Government of India. Health Information of India, 2007. New Delhi: CBHI, DGHS, MOHFW; 2008.

69. Government of India. Health Information of India, 2008. New Delhi: CBHI, DGHS, MOHFW; 2009.

70. Government of India. Health Information of India, 2009. New Delhi: CBHI, DGHS, MOHFW; 2010.

71. Government of India. Health Information of India, 2010. New Delhi: CBHI, DGHS, MOHFW; 2011.

72. Government of India. Health Information of India, 2011. New Delhi: CBHI, DGHS, MOHFW; 2012.

73. Government of India. Census of India, 2011. New Delhi: The Registrar General Office; 2012. 